\title{
„Rocznik Andragogiczny” 2013, Wydawnictwo Naukowe UMK, Toruń 2013, ss. 564
}

„Rocznik Andragogiczny” 2013 składa się z siedmiu działów: Edukacja dorostych- kompetencje-rynek pracy, Wyzwania starzejącego się społeczeństwa, Z historii teorii i praktyki edukacji dorostych, Edukacja dorostych za granica, Raporty z projektów badawczych, Aktualia oraz Recenzje. Ponadto zawiera sprawozdanie z II Zjazdu Andragogicznego, autorstwa Hanny Solarczyk-Szwec i Kingi Majchrzak, którego tematem przewodnim była teoria i praktyka edukacji dorosłych w procesie zmian, oraz Felieton Jerzego Półturzyckiego, który wieńczy dwudzieste wydanie „Rocznika”.

Pierwszy dział „Rocznika”, składający się z sześciu tekstów, otwiera artykuł Hanny Solarczyk-Szwec Od kapitatu adaptacyjnego do rozwojowego Polaków. Niektóre uwarunkowania zmiany. Autorka, dokonując analizy rozmaitych raportów z badań oraz publikacji dotyczących różnych sfer życia w Polsce, koncentruje się na takich zagadnieniach jak: bariery rozwoju cywilizacyjnego, kapitał dzieci, postawy współczesnej młodzieży, potencjał dorosłych do zmiany czy zależność między poziomem alfabetyzacji w dzieciństwie a jakością życia w dorosłości.

Alicja Jurgiel-Aleksander oraz Adam Jagiełło-Rusiłowski w artykule Dyskurs uczenia się przez całe życie: administrowanie kompetencjami czy pytanie o ich sens i znaczenie? rozważają znaczenie koncepcji całożyciowego uczenia się (Life Long Learning), biorąc pod uwagę sposób podejścia do kompetencji. Zdaniem Autorów przyjęty wzorzec kompetencji niesie za sobą określone konsekwencje w takich sferach jak organizacja procesu uczenia się czy tematyka badań podejmowanych przez badaczy edukacji. Grzegorz Sanecki w artykule Postrzeganie własnych kompetencji zawodowych przez studentów pedagogiki UMCS przedstawia wyniki swoich badań, w których starał się ustalić poziom umiejętności zawodowych oraz kompetencji społecznych nabywanych przez studentów w okresie studiów. Anna Kowal-Orczykowska wraz 
z Anną Pabiańczyk przyglądają się działaniom podejmowanym przez studentów pedagogiki w celu zwiększania przez nich własnej konkurencyjności na rynku pracy, a Krzysztof Rubacha oraz Mariana Sirotova dokonują porównania skuteczności wychowawczej kandydatów na nauczycieli w Polsce i Słowacji, chcąc sprawdzić, czy system kształcenia pedagogów, tak bardzo różny w obu krajach, ma wpływ na poziom odczuwanej skuteczności.

Część pierwszą „Rocznika” zamyka raport z badań Agaty Wołowskiej, w których Autorka sprawdzała związek poziomu satysfakcji z pracy urzędników z jakością ich życia. Wyniki badań pokazały m.in., że poczucie bezpieczeństwa oraz relacje ze współpracownikami są kluczowe przy odczuwaniu zadowolenia $\mathrm{z}$ pracy, a satysfakcjonująca praca dodatnio koreluje z poczuciem jakości życia, co potwierdza rolę aktywności zawodowej w życiu człowieka.

Kolejny dział „Rocznika”, złożony z ośmiu artykułów, otwiera publikacja Elżbiety Dubas Starość znana i nieznana - wybrane refleksje nad wspótczesnq starościq, w której Autorka analizuje stan wiedzy naukowej oraz świadomość ludzi odnośnie do starzenia się oraz starości. Podejmuje zagadnienie problemów, z jakimi borykają się starsze osoby, a także stereotypów krążących na ich temat, starając się nakłonić nas do patrzenia na ten etap życia jak na wartość, z której można czerpać. Artykuł O szczęściu w uczeniu się autorstwa Sabine Schmidt-Lauff dotyczy problematyki szczęścia, jakie można odczuwać w procesie edukacji. Tematyka podjęta przez Autorkę jest swoistym ewenementem, ponieważ większość publikacji koncentruje się na ograniczeniach bądź trudnościach związanych z uczeniem się. Małgorzata Malec-Rawiński w artykule Znaczenie krytycznej gerontologii edukacyjnej dla badań i praktyki porusza kwestię edukacji osób starszych na Uniwersytetach Trzeciego Wieku, zastanawiając się nad działaniami mogącymi zwiększyć jej efektywność. Zdaniem Autorki efektywne uczenie na UTW może zachodzić wtedy, gdy pod uwagę brane są takie kwestie jak: jasno wytyczone cele edukacji, odpowiednio dobrane środki, metody i formy dydaktyczne oraz znajomość psychologii osoby starszej. Artykuł Uczenie się jako strategia pozytywnego starzenia się autorstwa Renaty Koniecznej-Woźniak podejmuje wątek zagospodarowania potencjału osób starszych przez angażowanie ich w działalność edukacyjną. Autorka odwołuje się do koncepcji pozytywnego starzenia się Roberta Hilla, zakładającej wykorzystanie przez człowieka dostępnych zasobów w celu zneutralizowania skutków starzenia się. Z kolei János Szigeti Tóth zwraca uwagę na rolę mediów społecznościowych w życiu osób starszych i ich edukacji. Autor skupia się w swoim artykule na takich kwestiach jak: korzystanie z portalu Facebook według kategorii wiekowej, potrzeby edukacyjne osób starszych na świecie i na Węgrzech czy korzyści pły- 
nące z użytkowania portali społecznościowych przez seniorów. Komunikacja międzypokoleniowa w rodzinie stanowi temat przewodni artykułu Zdzisława Aleksandra. Autor porusza problem rosnących trudności w porozumiewaniu się między ludźmi młodymi a ich rodzicami, podkreślając konieczność wypracowania wspólnego języka, który umożliwi nawiązanie efektywnego dialogu, tak bardzo potrzebnego w procesie uczenia się.

Marzenna Zaorska porusza w swoim artykule zagadnienie statusu społeczno- zawodowego niewidzących kobiet w wieku 50+. Autorka ubolewa nad stosunkowo niewielką partycypacją rzeczonej grupy w życiu społeczno-zawodowym, jako przyczyny podając m.in.: niskie kwalifikacje, niedostateczny poziom wykształcenia czy niewłaściwe nastawienie mentalne. Jakość życia nauczycieli emerytów i rencistów stanowi oś rozważań Krzysztofa Andrzeja Zajdla, autora artykułu, który zamyka drugi rozdział „Rocznika”.

Dział trzeci „Rocznika Andragogicznego” 2013 rozpoczyna się od artykułu Władysławy Szulakiewicz, w którym Autorka omawia istotę oraz sens badań biograficznych, podając ich możliwe zastosowania w ukazaniu dziejów andragogiki. Zdaniem Autorki konieczne jest stworzenie profesjonalnego słownika pojęć andragogicznych, w którym mogłyby się znaleźć takie zagadnienia jak: pionierzy andragogiki, osoby zasłużone dla jej instytucjonalizacji czy twórcy programów edukacji dorosłych.

W kolejnym tekście Józef Półturzycki przypomina sylwetkę Haliny Szwarc - organizatorki uniwersytetu trzeciego wieku w Polsce, w rocznicę jej 90 urodzin. Autor dokonuje szczegółowej rekonstrukcji biografii, począwszy od czasów młodości, w których zajmowała się działalnością konspiracyjną, przez okres powojenny, w którym rozwijała swoje życie osobiste i zawodowe, aż do czasu tworzenia przez nią UTW. Dzięki takiemu ujęciu możemy poznać Halinę Szwarc z wielu perspektyw. Z kolei Tadeusz Aleksander prezentuje biogram Marii Borowieckiej - popularyzatorki idei edukacji dorosłych z okresu dwudziestolecia międzywojennego. Autor szczegółowo przedstawia życie Borowieckiej, koncentrując się na jej karierze zawodowej i współpracy z wieloma osobistościami, która zaowocowała niezwykle prężnym rozwojem edukacji dorosłych. Jiří Pavlů przybliża postać Jana Amosa Komeńskiego, omawiając jego poglądy, przypominając najważniejsze dzieła i pokazując, że idee czeskiego pedagoga nie straciły na aktualności mimo upływu wieków.

Tekst Od miejsc pamięci narodowej do miejsc żywej pamięci - implikacje dla pedagogiki autorstwa Kingi Majchrzak, zamykający trzecią część „Rocznika”, pokazuje możliwości wykorzystania pedagogiki miejsca do rozwoju edukacji dorosłych. Zdaniem Autorki miejsca pamięci dzięki ich symbolicz- 
nej naturze mogą stanowić impuls do samowychowania, samokształcenia czy też sprzyjać rozwojowi refleksyjności, co jest szczególnie ważne w przypadku edukacji całożyciowej.

Czwarty dział Edukacja dorostych za granica złożony jest z trzech publikacji. Olga Czerniawska podejmuje tematykę edukacji dorosłych we Włoszech na przełomie XX i XXI wieku. Autorka omawia włoski system kształcenia dorosłych, oparty na indywidualizacji nauczania, przez co uwzględnia potrzeby i oczekiwania uczestników. Antra Carlsen dokonuje omówienia skandynawskiego systemu edukacji dorosłych, które w dużej mierze opiera się na sieci i sieciowaniu. Z kolei artykuł Szansa na lepszą przyszłość. Edukacja dorosłych w systemie penitencjarnym Azji Środkowej Tatiany Zaiczenko opisuje działalność organizacji DVV International zajmującej się edukacją dorosłych, na przykładzie zajęć w zakładach karnych na terenie Uzbekistanu, Kirgistanu i Tadżykistanu.

W dziale piątym "Rocznika” możemy znaleźć trzy raporty z badań. Pierwszy z nich Mikroświaty macierzyństwa autorstwa Martyny Pryszmont-Ciesielskiej stanowi opis badań, w których starano się zilustrować status społeczny matek, pokazać ich potencjał oraz uwrażliwić ludzi na macierzyństwo. Anna Gutowska przedstawia wyniki badań swojej pracy doktorskiej, której tematem była przyjaźń osób dorosłych i uczenie się w sytuacji przyjaźni, a Alina Matlakiewicz i Anna Matusiak dokonują analizy wyników uzyskanych przez Polaków w Międzynarodowym Badaniu Kompetencji Dorosłych (PIAAC).

W Aktualiach możemy przeczytać sprawozdania z rozmaitych konferencji, takich jak: „Kształcenie ustawiczne dla potrzeb rynku pracy”, „Profilaktyka, wsparcie i resocjalizacja a środowisko lokalne. Perspektywy krytyczne”, „Aktywizacja seniorów - między powinnością a profesją - kształcenie i działanie” czy „Biografia i badanie biografii - osobliwości biografii edukacyjnych". Ponadto znajdziemy tam relację z realizacji projektu badawczego „Regionalna Sieć Uniwersytetów Trzeciego Wieku Wyższej Szkoły Gospodarki w Bydgoszczy szansą rozwoju kulturalnego i artystycznego Seniorów", a także sprawozdania z działalności Zarządu Akademickiego Towarzystwa Andragogicznego czy Jubileuszu trzydziestolecia Kaszubskiego Uniwersytetu Ludowego. Dział podsumowują trzy zaproszenia na konferencje andragogiczne: VIII Łódzką Konferencję Biograficzną „Biografia i badanie biografii - biografie edukacyjne w kontekście całożyciowego uczenia się", VIII Zakopiańską Konferencję Andragogiczną „Społeczno-kulturowe aspekty czasu w kontekście uczenia się dorosłych" oraz na XVI Letnią Szkołę Andragogów i Poradoznawców odbywającą się w Zielonej Górze. 
„Rocznik Andragogiczny” 2013 zamyka dział Recenzje, w którym możemy znaleźć omówienia i ocenę 23 publikacji z zakresu edukacji dorosłych, koncentrujących się na takich zagadnieniach jak np. wykorzystanie potencjału osób starszych, sytuacja osób dorosłych z niepełnosprawnością, kształtowanie prężności psychicznej, metody prowadzenia szkoleń z osobami dorosłymi, doświadczenia biograficzne polskich emigrantów, kapitał społeczny osób starszych czy pedagogika innowacyjności. Tradycyjnie, kolejny już tom „Rocznika” kończy Felieton, pióra Józefa Półturzyckiego, w którym autor dokonuje rozważań nad znaczeniem liczby 13 dla rozwoju kultury i nauki.

Dwudzieste wydanie „Rocznika Andragogicznego”, debiutującego w nowej szacie graficznej, zawiera wiele cennych danych, zarówno z punktu widzenia teorii, jak i praktyki edukacji dorosłych. Ponadto, stanowi bogate źródło informacji o wydarzeniach mających miejsce w świecie andragogiki oraz publikacjach, dzięki którym można poszerzyć swoją wiedzę o funkcjonowaniu, rozwoju i zagospodarowaniu potencjału osób dorosłych. Recenzowana publikacja powinna na stałe zagościć u osób chcących wzbogacić się o kolejne kompendium wiedzy andragogicznej. 